\title{
ERICH FROMM'S THEORY: THE NATURE OF HUMAN SOUL, ALIENATION AND ESCAPE FROM FREEDOM
}

\author{
Asatulloev Inomjon \\ Researcher, \\ Ferghana State University \\ Ferghana, \\ Uzbekistan.
}

Article DOI: https://doi.org/10.36713/epra2523

\begin{abstract}
The article analyzes the philosophy of Erich Fromm, the human heart, goodness and evil inclinations, sadism, the problems of freedom of worship, human destructiveness, various forms of aggression, contradictory necrophilia and biophilia. In the philosophy of Erich Fromm, the heart of the human soul is shown by the desire for destructive desires and the uplifting desires - love for humanity and freedom. Our goal is to analyze the souls of human minds based on the works of the intellectuals. From the Erich Fromm heart concept, the robotic personality and the character of the stranger are disclosed.
\end{abstract}

KEY WORDS: sadism, heart, egoism, violence, weakness, alienation.

\section{INTRODUCTION}

The indifferent attitude to life in the age of technological advancement forms the question of studying the human heart in the philosophy of Erich Fromm, the well-known 20th-century thinker. In today's world, people are becoming more and more interested in learning the human heart while increasing their hatred for life. Therefore, it is necessary to understand the essence of human beings.

Capitalism has also changed the rules existing in the traditional society. In the general psychology of society, egoism and interest are intensified.

Erich Fromm examines the dangerous forms of human failure. As a result of violence, violence, jeopardy, intoxication, rebellious violence, and thirst for blood. Erich Fromm explores the possibility of corruption in the human heart, describing corruption as a means of escaping a sense of imperfection. An analysis of Fromm's biophilia and necrophilia concepts suggests that Freud has similar and different aspects of life and death instinct. Fromm, in his own eyes, attaches great importance to "narcissism" (selfesteem).

Fromm is suggested that the essence of any neurosis, as well as normal development, is a struggle for freedom and independence.

\section{RESULTS AND DISCUSSION}

Erich Fromm analyzes the essence of evil in the human heart, the issues of goodness and evil, sadism, the problems of freedom of worship, the destruction of man, various forms of aggression, and contradictory biophilia and necrophilia.

From the philosophy of Fromm, the philosophy of human souls is the study of the love for the destructive desires (dead, corpses), the stubborn narcissism and the symbiosis-intentional aspirations and the uplifting desires, and the love of freedom.

Before analyzing the human heart, it is necessary to understand human beings and understand its essence. Fromm is a man created by man's evolutionary development in philosophical anthropology, and the environment surrounding itself goes beyond the previously adapted circle [10.159]. According to Fromm, man is the creature, but not better than the other creatures. Therefore, it is guaranteed that it will satisfy its needs, develop its own tools, and develop its own language. According to Fromm's view, man possesses another spiritual character, which is not found in any other creature. He thinks himself about his past and future. He accepts his own futility and his future. Human beings are in nature. Therefore, it is subject to its verdict and change. He realizes that humanity is involved in tragic conflicts. He is a captive of nature, yet he is 
free to think in his own thoughts. The same is true of her being, her own being, lonely and fearful [10.192].

Erich Fromm examines the dangers of man's destruction in his research. Knowing less severe forms of violence helps to better understand the abnormal and dangerous forms of failure. It is therefore important to analyze the forms of violence.

Erich Fromm explores the perversion of human heart and describes corruption as a means of escaping a feeling of inadequacy. As a result of loneliness and weakness, the external world seems to be threatening and causes anxiety in an unseen condition. Also, man feels his emotional, emotional, and intellectual capacities are limited in this situation [12.151].

The issue of corruption and restrictions was initially analyzed by Freud, which stated that sexual orientation would change the behavior of the human being and stimulate his behavior. He later said that there are two basic forces, such as the pursuit of life and the destruction of life, namely the quest for corruption. But in Freud, this process is not biologically interpreted as perfect.

Fromm says that the trend of destructiveness can be formed not only in the individual, but also in different social groups. It follows that Fromm concludes that social factors influence not only the biological factors but also the formation of the sense of corruption. This approach reflects the differences between Freud and Fromm's views.

Fromm looks at the essence of the mischief and concludes. "The more a person's aspiration for life is, the more destructive tendencies it will be; the more likely the pursuit of life will be, the stronger the tendency to corruption. Extortion is the result of a lifeless life. Life-time individual or social life creates passion for corruption"[12.152].

There is a power of human power in power, and it is directed towards a specific goal. If a person is frail, coward, ignorant, unkind, and unknowingly, he will suffer and destroy his inner balance.

Fromm, he analyzed his ability to do good and evil in the human heart, suggesting that humans are inclined to dominate and subordinate to the cubic and behemoth types. Thinker discloses the tendency to seek dominance or obedience to man's dominance by means of the masochistic and sadistic features in them.

Masochistic quality is a desire for human beings to obey the other man, the structure, and God, that is, to get rid of loneliness. Sadist, on the other hand, wants to dominate and redirect his own judgment and will. The obvious manifestation of this unhealthiness leads to admiration, when instead of joining people, to the inner subjective world. Anxiety, fear, and depression are suddenly becoming ignorant and create disorder, that is, a desire to destroy the hostile world. Homosexual traditions are meaningless and unnatural, says Fromm. But in most cases it is acceptable, and the masochistic practices are realized in love or loyalty mask, the complex of imperfections compensates for the real flaws and the suffering is overwhelming. The opposite side of masochistic tradition is sadistic (cruel). It is strong or weak, fully or partially understood, but it is rarely seen that it is not entirely possible[13.112].

Fromm shows 3 types of sadistic tendencies. Firstly, dependency on other people and their control over them; The second is not to have absolute control over people, but to exploit them. The sense of ownership is not only a material property but also a moral and intellectual character; the third one is seen by torturing other people and suffering from them [10.197].

Masochistic and sadistic tendencies are covered with masks such as anxiety and care for others. If the masochistic dependence is evident, the sadist needs his own, as he feels his strong feelings are based on the fact that he is the master. In fact, people can give everything they can to their subjects - love, respect, and respect, but not just a nova - the right to freedom and independence.

Fromm is questionable as to the magical symptoms of the character and the origin of the disorder. That is, what are the common signs of the masochistic and sadistic tendencies? According to Fromm, magical and sadistic aspirations help the individual to cope with the unbearable suffering of loneliness and weakness. Psychoanalytic observations on the Masochistic indicate that the sense of loneliness and the feeling of their inability are growing stronger. Fromm writes: "In Masochism it is active because of the indefinable sense of indifference and loneliness. He wants to abandon his psychological sense of I; for this he is humiliated, suffers, and drives himself to excessive subsistence "[12.149]. Although sadism and corruption are interconnected, it is not the same thing. An oblivious person seeks to destroy an object, that is to say, the sadist tries to dominate the object and suffers when it loses it.

Fromm believes that thirst for power does not depend on power, but on weakness. When power is dominated one by one, power is the ability to change force. "If man is strong, that is, he is capable of realizing his potential on the basis of the freedom and integrity of his own self, he has no need to rule over humans, and he does not seek power." [12.152]

Fromm, separating authority from inside and outside, emphasizes that the inner power acts as a duty, conscience, and writes about conscience. "Conscience is far more cruel than the external powers, and the content of conscience is often incompatible with the moral norms of human dignity $[12,207]$. The conscience can be overwhelming with its toughness, because it can not be ruled out by human conscience. How can he go against himself? To this day, "conscience" has lost much of its power. Everyone is absolutely free if they do not violate the legitimate rights of others. " 
The human mind, who claims to be inclined to violence, is also inclined to corruption, enmity and envy, analyzes the factors that make the human being destructive.

Historical sequences have developed feelings such as weakness, fear and new character traits - enmity and jealousy have begun with the rise of capitalism. "The element of hostility is that, as a result of competition, or conflict of interest and many other situations, emotional and emotional needs of a person are suppressed and suppressed. It creates a sense of hostility. "[12.192]. Enmity and envy have a tendency toward despair and anger toward people. Enmity in humans will be directed against another and against God. The only way to get rid of hostility is self-defeating. The believer who is seen in the people says that his anger and hatred towards him are hidden in him. We can see the self-centered hatred of man as we try to make his distorted and ineffective feelings. Or it is manifested by true humility and commitment. With the sense of duty, we can see real self-esteem in a man. Fromm writes about it. "True humility, the sense of true duty for the people is incompatible with disbelief and hatred of people; but self-condemning and self-denial "conscience" is one aspect of hostility, and the other is hatred and doubts [12.216]. " Fromm believes that manifesting the true conscience of man is driven by hatred and enmity toward him. According to Fromm, "Conscience" is a human observer. It urges us to act in harmony with the wishes and goals that we consider to be ours. Conscience gives human beings the power of judgment and cruelty. He forbids happiness and happiness for him, and his life forces him to mysterious sin.

Capitalism has also changed the rules existing in the traditional society. Newly shaped character and qualities. The powerful force that moves human activity is self-interest and egocentrism. This process has led to individual selfdetermination. However, self-denial and asceticism appeared in society. In the general psychology of society, egoism and interest are intensified.

According to Fromm, egoism is a form of treachery, and it involves incompetence, like any feverishness. Covetousness is a deep depression that can freeze a person; humanity wants to meet this need because of infinite suffering, whereas it will never be satisfied. Careful observations show that the egoist is never satisfied, even though he is always busy with himself. " Because envy is strong in it. He always thinks that he lives and that he has lost something and that he has something to lose. According to Fromm, such people are not surprised by themselves; they hate themselves at the bottom of their heart. "Egoism is the lack of love for self [12.226]," says Fromm.

The psychological and moral behavior of human beings is that there is not much difference between biophilia and necrophilia. A human being is not completely biophilic or non-necrophilic. In many people, there are both kinds of biological and neurological disorders. It is noteworthy that one is more likely to manifest in human relationships than in the absence of one of the two beings [14.36].

When analyzing the necrophilic tendency, it is necessary to consider the specific features. Necrophilic features include the desire to kill, mischief, violence, and sadism. In one man, one of the above can be expressed in more ways, and the other can be clearly seen in the other person.

The contradiction of the necrophilic tendency is biophilia, which means love of life. It also has its own attributes. This phenomenon emerges in the biological, emotions, mentality, and social relationships of man. The desire to love life is seen in all living things around us. An attempt to survive, to fight death, and to love life are the most primitive aspects of biophilia. Biophilia is the result of more creativity. Man maintains what he has, but he tries to add and create new ones. He wants to make a human being better, with love, rather than a corrupt attitude, as if looking at an inanimate object [14.45].

Biophilia morality also has its own positive and negative aspects. Goodness is respect for life, development, and openness to the news. Everything that puts life, restraints, and kills life is evil. A person who loves life does not hate himself, nor does he live long in the sense of regret and guilt. Many people have a specific contrast to the desires of mortal and lifelessness, and the importance of which is managing man. Humans, who are more likely to be mortal, are slowly killing themselves.

The most effective way to encourage them to live in a child is to be with those who love life. As the baby grows warm and kindly with others, it feels free, away from threats, trained to communicate through the examples not only through correlation, but also as a guide for living art and a truly lifelike lifestyle [4.50]. The conditions that appear above are the basis for enhancement of the nervous system.

The social conditions that are needed for the strengthening of biophilia are the same as those creating conditions for individual development. The main thing is that the abundance of economic and spiritual needs will increase the eagerness of living. The vast majority of human capacities are to ensure the survival of corruption. Another condition that makes the desire for life to grow is the disappearance of this injustice. It explains the way in which the person creating the injustice is not his own purpose, and that he is used as a tool for the benefit of another person. And finally, it is a freedom that makes life stronger. It is not enough to be free from political barriers that limit people. Having the right to do something to increase the desire to live is more important. You must be active and responsible person to feel that freedom. Fromm emphasizes that the 
passion for living will be strong in a society with security, justice, and freedom.

Security: Failure to remain in danger of the fundamental economic conditions essential for a prosperous life; justice: no one should use another person as a tool for their purposes; freedom: everyone has an opportunity to become an active and responsible member of society [14.51]. Indeed, it is crucial that people in the community be safe, free and fair. Social conditions, not just the eagerness to live in, create the conditions for robots to rise, but also the mortality. An analysis of Fromm's biophilia and necrophilia concept suggest that Freud has similar and different aspects of life and death instinct.

Fromm to the social conditions that shaped the necrophilia, the question of why mankind is on the verge of a nuclear strike. In his opinion, there are many wars in history, but the reasons for wars protection against aggression, economic deficiency, aspiration to freedom, honor and dignity, prosperity should not be enough for a nuclear strike. The nuclear war in a matter of minutes creates a threat to the extinction of humanity, and claims that there is no meaning in life for countless survivors.

Why is nuclear disarmament being prepared today? Why Does Humanity Unite to Fight Nuclear War? Why do people have a strong desire to live and have enough resources and possibilities to live in such a state? "Fromm says that people are not afraid of the complete disappearance, lack of desire to live, and lack of interest in surviving [14.55]. Fromm, who examines the individual and social perception of one of the evil inclinations of the human heart, analyzes the role of nationalism, ethnic hatred, war and corruption.

Fromm attach great importance to "narcissism" (self-esteem). In his opinion, man's good and evil abilities are manifested by destructive or creative aspirations at the level of unconsciousness. The forces of corruption represent the aspiration to death, self-esteem (narcissism), and enthusiasm to the crowd. The Creator's forces, in contradiction with them, are: to pursue life, to love others, and to be self-reliant. According to Fromm, the state of narcissism is spiritual energy. This causes a person's inner biological power to shock [10.175]. A complete victory over Narcissism is accomplished through the idea of "Be friendly to your enemy." Fromm says, "It is possible only to freeze the believer or the enemy, only when I am inferior to another" [15.89]

Erich Fromm, according to the concept of the heart, constitutes the essence of any neurosis as well as normal development - a struggle for freedom and independence. For many ordinary people, this struggle has fallen: this struggle ended with a complete surrender; they sacrifice their personality, they are well adapted and normal people. Neurotic it can be understood as an ineffective attempt to resolve the conflict between resistance to complete obedience and the intrusion of neurosis with its inescapable dependence.

In the 20th century, the problem of alienation has become a major issue. One of the main reasons for this is the loss of affection among the people and the substitution of material interests. In such a society, a person becomes deprived of his dignity and becomes a property. It is customary for all people to look at their possessions and to use their benefits in the family or in the ministry. As a result, says Fromm, the feelings of a person in the inner world are completely ignored. Instead, it is selfish. But selfishness satisfies the deeply rooted feelings of human nature. That is, selfishness can lead to depression and loss of interest in life. When life's interest and emotions disappear, the desire to die under the guilty consciousness of one's mind becomes worse. Hence, in today's developed societies, self-mortality rates are rising. From that point of view, Fromm believed that the rise of love for each other, the emotional uplifting and the further improvement of the spiritual world. A strong man who is in love ensures the continual elevation $[10,189]$.

Man wants to get out of the fear of loneliness and loneliness. He tries to get rid of the burden of self-sufficiency and suffering. For many years, man has been trying to get rid of the craziness.

\section{CONCLUSIONS}

Erich Fromm summarizes the analysis of the individual features of robotics in the concept of the heart. In today's society, human robotics can further anger the average person's weaknesses. Therefore, he comes to believe that he is ready to submit to the new authority, which will give him self-confidence and relief from doubts.

In short, the desire to live in society is decreasing. The struggle for the sake of human upbringing in the society, and the failure to live in peace, have caused unease and tension in the world of forgetting the dangers facing the world. Today's attitude to life has become mechanic. Unfortunately, human beings are not created as lifeless. When it comes to something, it disappears, before the end of the cycle, people are desperate, and they want to live and to destroy life. Fromm modern society has shaped robust desires in humans. That's why today's people have been given names like "factory man", "robot man", "consumer".

It has been revealed that by stopping people from becoming robots, raising their souls, shaping good-natured personalities and protecting the destiny of humanity from degeneration, and, most importantly, creating a social heart is becoming an important issue.

Within the scope of the research, it can be used to draw on its conclusions in expanding the philosophy of social-philosophy, understanding the human mind, and developing methodological 
developments for scientific explanation of the desires and inclinations of the heart. Nowadays, it is important to study and analyze various doctrines, to make the right conclusions, and to formulate the spirituality of our youth.

\section{REFERENCES}

1. Egorova I.V. (202): Philosophical anthropology of Erich Fromm. -Moscow: pp. 138-164. (Егорова И.В. Философская антропология Эриха Фромма. -М., 2002. -164 с.. http://www.disscat.com/images.)

2. Atsiz H. (2006): Evolution of Erich Fromm's humanistic understanding of religion in today's societies. Directorate of Social Sciences Institute of Ondokuz Mayls University. Samsun: pp. 57-64 (Hasan Atsiz, Erich Fromm'un hümaniter din anlayişinin günümüz toplumlari açisindan değerlendirilmesi. Samsun-2006. Ondokuz Mayls Üniversitesi Sosyal Bilimler Enstitüsü Müdürlüğ̈̈)

3. Güner M.(2012): Erich Fromm's moral understanding. Gazi University. Institute of Social Sciences. Ankara: pp. 87-96 (Güner M. Erich Fromm'un ahlak anlayişi. Gazi üniversitesi. Sosyal bilimler enstitüsï. Ankara2012.)

4. Mauricio Cortina M.D.(1996): The Greatness and Limitations of Erich Fromm's Humanism, Contemporary Psychoanalysis. pp. 388-422.

5. O'Conor J. (1996): Erich Fromm: The aloneness of man. New York: pp. 61-65.

6. Ian Raymond B. Pacquing (2013): The Power of Man in Fromm's Humanistic Ethics. pp. 33-39

7. Miyamoto K. (2014): Erich Fromm's theory on alienation." (1987). Masters Theses 1911February 2014. 2481. Retrieved from htts: //scholarworks.umass.edu/theses/2481.

8. Marianne Horney Eckardt. (1994): Fromm's Concept of Biophilia. 3066-A Via Serena South, Laguno Hills, Ca 92653,

9. Funk R. (1982): Erich Fromm: The courage to be human. New York. pp. 132-138

10. Ruzmatova G.(2014): Philosophy of spiritual analysis. Tashkent: pp. 158-205. (Рузматова Г. Рухият тахлили фалсафаси. -Т.: "Нишонношир", 2014.)

11. Alimasov V.(2007): Human Disorder (Read Erich Fromm). Philosophy or thirst for thinking. - Tashkent: Institute of Philosophy and Law, рр.110-122 (Алимасов В. Инсон таназзули (Эрих Фроммни ууқиб). -Б. 110-122 // Фалсафа ёхуд фикрлаш чанқоги. - Тошкент: Фалсафа ва хукуқ институти нашриёти, 2007.)

12. Fromm E. (1996): Escape from Freedom. Translated by: Şemsa Yeğin. Ankara. pp. 140226 (Fromm E.Özgürlükten kaçiş. 4. Basım. Ceviren: Semsa Yeğin. Ankara. Teknografik Matbaası. 1996. 226)

13. Fromm E. (1990): Escape from freedom. Mosow: рр. 110-115 (Фромм Э. Бегство от свободы. M.: Прогресс, 1990.)

14. Fromm E. (1990): Source of love and violence, Translators: Yurdanur Salman, Nalan Iten.Istanbul: pp.25-55 (Fromm E. Sevginin ve şiddetin kaynaği, Çevirenler: Yurdanur Salman, Nalan Içten. 5. Basım, Istanbul, Payel yayınevi, 1990, -s.36)

15. Fromm E.(1992): The heart of man. Translator: P. S.Gurevich. Moscow: pp. 80-158. (Фромм Э. “Душа человека" Общ. ред. П.С.Гуревич. М; изд-ва «Республика» 1992.) 